Tropical Journal of Pharmaceutical Research October 2020; 19 (10): 2041-2045

ISSN: $1596-5996$ (print); 1596-9827 (electronic) (C) Pharmacotherapy Group, Faculty of Pharmacy, University of Benin, Benin City, 300001 Nigeria.

\title{
Effect of "HuChou San" on ABCC11 mRNA levels and MRP8 protein expression in skin tissue from bilateral axilla of axillary osmidrosis patients
}

\author{
Bin Chen ${ }^{1}$, Huichun Wang ${ }^{1}$, Baojin Wu ${ }^{2 *}$ \\ ${ }^{1}$ Department of General Surgery, Huangpu Branch, Shanghai Ninth People's Hospital, Affiliated to Shanghai Jiaotong \\ University, School of Medicine, ${ }^{2}$ Department of Plastic Surgery, Huashan Hospital, Fudan University, Shanghai 200040, China
}

*For correspondence: Email: wbshhs@aliyun.com; Tel/Fax: +86-021-52889999

Sent for review: 5 December 2019

Revised accepted: 22 September 2020

\begin{abstract}
Purpose: To investigate the effect of "HuChou San" on axillary osmidrosis (AO) by measuring ABCC11 mRNA levels and MRP8 protein expression in axillary skin tissues from "HuChou San"-treated AO patients.

Methods: Forty AO patients undergoing treatment at Shanghai Ninth People's Hospital were enrolled in the study. Tissues from axillary regions were initially treated for $10 \mathrm{~min}$ with a solution of copper sulphate and zinc sulphate, followed by treatment with gentle application of "HuChou San" once daily for 3 months. Ten healthy individuals served as untreated control. Axillary skin tissue was surgically collected at 0, 1, 2, and 3 months of treatment. The expressions of ABCC11 mRNA and MRP8 protein in axillary skin samples were determined using $q P C R$ and Western blot, respectively.

Results: The qPCR and Western blot results showed higher levels of ABCC11 mRNA and MRP8 protein in AO patient tissues than in healthy controls. However, "HuChou San" treatment markedly reduced tissue levels of ABCC11 mRNA and MRP8 protein $(p<0.05)$, when compared to tissues extracted prior to treatment. These effects were time-dependent and increased as treatment duration increased $(p<0.05)$.

Conclusion: "HuChou San" powder significantly and time-dependently reduced ABCC11 mRNA and MRP8 protein expressions in $A O$ axillary tissue of $A O$ patients. It is known that ABCC11 mRNA and MRP8 protein are two important indices of AO. Therefore, the findings of this study suggest that "HuChou San" has potentials for use as a novel alternative therapy for AO.
\end{abstract}

Keywords: ABCC11 mRNA, MRP8 protein, Axillary osmidrosis, HuChou San

\begin{abstract}
This is an Open Access article that uses a funding model which does not charge readers or their institutions for access and distributed under the terms of the Creative Commons Attribution License (http://creativecommons.org/licenses/by/4.0) and the Budapest Open Access Initiative (http://www.budapestopenaccessinitiative.org/read), which permit unrestricted use, distribution, and
\end{abstract} reproduction in any medium, provided the original work is properly credited.

Tropical Journal of Pharmaceutical Research is indexed by Science Citation Index (SciSearch), Scopus, International Pharmaceutical Abstract, Chemical Abstracts, Embase, Index Copernicus, EBSCO, African Index Medicus, JournalSeek, Journal Citation Reports/Science Edition, Directory of Open Access Journals (DOAJ), African Journal Online, Bioline International, Open-J-Gate and Pharmacy Abstracts

\section{INTRODUCTION}

Axillary osmidrosis $(\mathrm{AO})$ is a clinical condition that manifests in an offensive and unpleasant body odour originating from the axillary area. This odour, which is produced by secretions from the axillary apocrine glands, can cause significant distress and impair the psychosocial well-being of the affected individuals. Many methods are used for treating AO. These strategies may be either in the form of drugs or in the form of surgical intervention. The use of 
conservative strategies such as topical application of astringents, systemic agents, or botulinum toxin, results only in transient therapeutic outcomes [1]. Since surgery may provide a permanent solution for the problem, surgical strategies are preferred by patients with more complicated cases of $A O$ [1-4].

Several surgical techniques have been developed for removal of the axillary apocrine glands. These procedures include removal of subcutaneous tissue, total excision of skin and subcutaneous tissue, ultrasonic liposuction, electrodessication, as well as sympathectomy. However, these surgical techniques have yielded variable results [5-7]. Although some of these techniques have been shown to be efficacious [1, 8], concerns still remain regarding their invasive tendency, potential complications, prolonged recovery time, and scar tissue potential. These concerns may influence the satisfaction of the affected individuals. Thus, newer surgical techniques have been evolved to overcome these undesirable side-effects. Herbs have also been used for AO therapy. Saponins, Halite violaceous, Rhizoma typhonii, and Impatiens balsam produce good effects on AO. "HuChouSan" has very strong therapeutic effect on $A O$, based on the results of a previous study. This prompted the present study aimed at further investigations on the efficacy of "HuChouSan".

The objective of this study was to investigate the effect of daily treatment with "HuChou San" powder on AO. Abnormal expressions of MRP8 and $A B C C 11$ have been linked to $A O$ [9]. $A$ strong positive preference for low-odorant partners with a dysfunctional ABCC11 gene seems a plausible explanation for this striking frequency of loss-of-function allele. Thus, the expression levels of ABCC11 mRNA and MRP8 protein were measured in skin tissues from the bilateral axilla of $\mathrm{AO}$ patients before and after "HuChou San" treatment.

\section{METHODS}

\section{Ethical considerations}

This study received approval from the ethical committee of HuaShan Hospital (approval no. $\mathrm{H} 201904$ ) in accordance with the Declaration of Helsinki, promulgated in 1964 and amended in 1996 [10]. All subjects provided written informed consent.

\section{Materials}

"HuChou San" powder consisted of saponin (25 $\%$ ), Halite violaceous (25\%), Rhizoma typhonii
(25\%), and Impatiens balsam (25\%). It was prepared by grinding together equal amounts of saponin, Halite violaceous, Rhizoma typhonii, and Impatiens balsam, into a fine powder.

\section{Patients, drugs and sampling}

A total of $40 \mathrm{AO}$ subjects (25 men and 15 women) undergoing concurrent treatment at Shanghai Ninth People's Hospital from July 2015 to July 2016 were selected as subjects for this study. The ages of the subjects ranged from 18 to 35 years (mean age $=23.7$ years). The subjects were treated with "HuChou San" powder according to the following procedure: patient axillary regions were initially treated for $10 \mathrm{~min}$ with a solution of copper sulphate and zinc sulphate. Then, "HuChou San" powder was applied gently to the affected region once daily for 3 months. Fresh skin tissue samples surgically collected from the bilateral axilla were preserved at $-70^{\circ} \mathrm{C}$ prior to analysis. The tissue specimens were collected from each participant at four time points. The first sample was taken prior to the initial "HuChou San" treatment (0 month sample), while the remaining samples were taken after the $1^{\text {st }}, 2^{\text {nd }}$ and $3^{\text {rd }}$ months of daily "HuChou San" treatment.

Ten healthy individuals (without $\mathrm{AO}$ ) were also selected as untreated, non-AO controls. Tissue samples were collected from the non-AO control patients at a single time point.

\section{Lysate preparation and Western blotting}

Lysates of frozen bilateral axillary skin tissue samples were prepared for Western blotting. The tissue samples were rinsed twice in ice-cold PBS, followed by lysing with RIPA buffer (Beyotime, Shanghai, China) containing $1 \%$ PMSF (Lullaby Pharmaceutical Chemical Co. Ltd, Wuhan, China). The lysates were ultrasonicated on ice, and subjected to brief centrifugation at $14,000 \times \mathrm{g}$ in the cold. The protein contents of the clear lysates were quantified using standard bicinchoninic acid (BCA) method, before denaturation.

Protein samples (10 - 50 $\mu \mathrm{g}$ total protein) were separated on SDS-polyacrylamide gel electrophoresis using 10 or $12 \%$ tris-glycine gels, and transferred to polyvinylidene difluoride (PVDF) membranes (KaiJie Membrane Seperation Technology Co. Ltd, HangZhou, China). The membranes were blocked with $5 \%$ non-fat milk, prior to incubation overnight with primary antibodies targeting MRP8 (ABCC11) (1:200; Santa Cruz Biotechnology, Santa Cruz, CA, USA) and $\beta$-actin $(1: 10,000 ;$ Bioss 
Antibodies, Beijing, China) at $4^{\circ} \mathrm{C}$. This was followed by incubation with goat anti-rabbit IgG (secondary antibody) conjugated to HRP (AmyJet scientific Inc, WuHan, China). Thereafter, the membranes were probed using ECL reagent (Solarbio Science \& Technology Co. Ltd., BeJing, China), followed by exposure to X-ray film (Fujifilm, Tokyo, Japan). The signal intensities of the protein bands were quantified using Quantity One software (Bio-Rad, Hercules, CA, USA). The MRP8 protein expression was normalized to that of $\beta$-actin which served as internal standard.

\section{Quantitative polymerase chain reaction (qPCR)}

Isolation of total RNA from bilateral axillary skin samples was done with RNX-Plus Solution (SinaClon, Iran). Using $1 \mu \mathrm{g}$ extracted RNA, cDNA was synthesised via reverse transcription with primers and M-Mel Reverse Transcriptase. The qPCR was carried out with an iQ5 RealTime PCR detection system and iQ5 Optical System software (Bio-Rad). The qPCR reaction mixtures comprised $1 \mu \mathrm{L}$ of cDNA, primer (0.6 $\mu \mathrm{L})$, GreenMaster Mix $(10 \mu \mathrm{L})$, and $20 \mu \mathrm{L}$ of PCR-quality $\mathrm{H}_{2} \mathrm{O}$.

The PCR primer sequences for $A B C C 11$ and $\beta$ actin are shown in Table 1. Each PCR assay was done in triplicate, and each experiment included negative and no template controls, using the following thermocycle: $94^{\circ} \mathrm{C}$ for $10 \mathrm{~min}$, then 40 cycles of $95^{\circ} \mathrm{C}(15 \mathrm{sec})$, annealing for $30 \mathrm{sec}$, and at $72^{\circ} \mathrm{C}$ for $25 \mathrm{sec}$. ABCC11 mRNA was quantified from qPCR data using the Pfaffl procedure, with $\beta$-actin gene as internal control [10].

Table 1: Primer sequences used

\begin{tabular}{ll}
\hline Gene & Primer sequence \\
\hline ABCC11 & Sense primer (5'- \\
& CTCCCACATCCTCAATTCTCTGC-3') \\
& Antisense primer (5'- \\
& GCCATCCATCGTGTGGAAGAT-3') \\
\multirow{3}{*}{-actin } & Sense primer (5'- \\
& GGGCACGAAGGCTCATCATT-3') \\
& Antisense primer (5'- \\
& AGCGAGCATCCCCCAAAGTT-3') \\
\hline
\end{tabular}

\section{Statistical analysis}

Statistical significance was determined using one-way analysis of variance (ANOVA), followed by the Tukey post-hoc test (if significant). Differences were considered significant at $p<0.05$. All statistical analyses were performed using GraphPad Prism (GraphPad Software, San Diego, CA, USA).

\section{RESULTS}

The MRP8 protein levels were significantly elevated in axillary tissue from untreated $A O$ patients, when compared to healthy control tissue $(p<0.05)$. One month of daily "HuChou San" treatment caused a significant decrease in MRP8 protein expression in AO patient tissue, relative to tissue taken before treatment $(p<0.05)$. Tissues obtained after 2 and 3 months of daily "HuChou San" treatment exhibited further suppressions of MRP8 protein expression, indicating that the effect of "HuChou San" treatment depended on the duration of the treatment (Figure 1).

The ABCC11 mRNA levels were significantly elevated in axillary tissue from untreated $A O$ patients, when compared to healthy control tissues $(p<0.01)$. One month of daily "HuChou San" treatment significantly down-regulated the expression of ABCC11 mRNA in AO patient tissue, relative to tissue taken before treatment $(p<0.01)$. Tissues obtained after 2 and 3 months of daily "HuChou San" treatment exhibited further decreases in ABCC11 mRNA levels (Figure 2).

\section{DISCUSSION}

Studies have demonstrated that human ABCC11 mRNA is produced in all foetal and adult tissues [11-13]. The ATP-binding cassette sub-family C member 11 (ABCC11) transports several biomolecules such as cyclic nucleotides, leukotriene C4 (LTC4) and S-(2,4-dinitrophenyl)glutathione (GS-DNP);
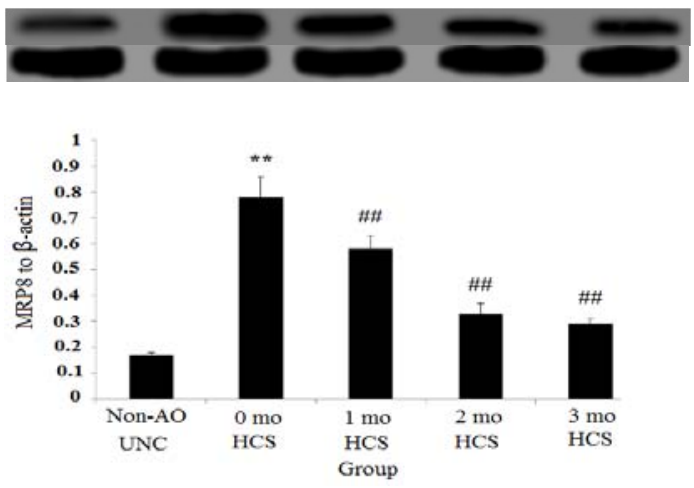

Figure 1: Effect of months of daily "HuChou San" treatment on MRP8 protein expression in bilateral axillary skin tissue of AO patients; ${ }^{* *} p<0.01$, vs nonAO UTC; ${ }^{*} p<0.05,{ }^{\#} p<0.01$, vs 0 month. (Non-AO $\mathrm{UTC}=$ non-AO untreated control; $\mathrm{HCS}=\mathrm{HuChou}$ San-treated AO patients; \# mo = months of daily HCS treatment) 


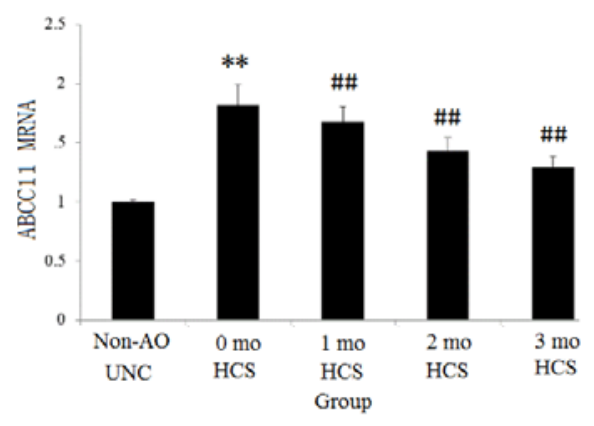

Figure 2: Effect of months of daily "HuChou San" treatment on ABCC11 mRNA expression in bilateral axillary skin tissue of $A O$ patients. ${ }^{* *} p<0.01$, vs nonAO UTC; ${ }^{\#} p<0.05,{ }^{\#} p<0.01$, vs 0 month HCS. (NonAO UTC = non-AO untreated control; HCS = "HuChou San"-treated AO patients; \# mo = months of daily HCS treatment)

steroid sulphates, glucuronides, and folic acid and its analogue methotrexate (MTX). The role of the MRP8 protein in the development of AO has been investigated $[14,15]$.

The present study shows that expression levels of MRP8 protein and ABCC11 mRNA were higher in axillary skin tissue obtained from $A O$ patients than in tissues from healthy (non-AO) individuals. In AO patients, "HuChou San" treatment time-dependently decreased the expression levels of MRP8 protein and ABCC11 mRNA in axillary skin tissue, when compared to tissues obtained from untreated patients. Abnormal expressions of MRP8 and ABCC11 may be used for clinical diagnosis of $A O$ [9]. "HuChou San" treatment decreased MRP8 protein and $A B C C 11$ mRNA expression levels in skin tissue from bilateral axilla of $A O$ patients. The results of the present study provide potential new direction for the treatment of $A O$.

\section{CONCLUSION}

This study has shown that AO patients' axillary skin tissue expresses markedly higher levels of ABCC11 mRNA and MRP8 protein than that of healthy patients. Treatment with "HuChou San" significantly decreases the expressions of $A B C C 11$ mRNA and MRP8 protein in AO patients' axillary skin tissue. Therefore, "HuChou San" may have some benefits as a therapy for AO.

\section{DECLARATIONS}

\section{Conflict of interest}

No conflict of interest is associated with this work.

\section{Contribution of authors}

This work was performed by the authors named in this article, and the authors accept all liabilities pertaining to claims relating to the content of this article. Bin Chen and Huichun Wang contributed equally to this work. Bin Chen and Huichun Wang performed experiments, collected data, and drafted the manuscript. Baojin Wu performed experiments.

\section{Open Access}

This is an Open Access article that uses a funding model which does not charge readers or their institutions for access and distributed under the terms of the Creative Commons Attribution License (http://creativecommons.org/licenses/by/ 4.0) and the Budapest Open Access Initiative (http://www.budapestopenaccessinitiative.org/rea d), which permit unrestricted use, distribution, and reproduction in any medium, provided the original work is properly credited.

\section{REFERENCES}

1. Mao GY, Yang SL, Zheng JH. Etiology and management of axillary bromidrosis: a brief review. Int J Dermatol, 2008; 47: 1063-1068.

2. Demitsu $T$, Nakamura S, Takazawa M, Kakurai $M$, Umemoto N, Kawase M. Axillary granular parakeratosis with osmidrosis successfully treated with topical maxacalcitol. J Dermatol. 2019; 46(5): e155-e157

3. Lin $L$, Huo $R$, Bi J, Meng $Z$, Cao $Y$. Fractional microneedling radiofrequency treatment for axillary osmidrosis: A minimally invasive procedure. J Cosmet Dermatol. 2019; 18(1): 115-120.

4. Yang $H H$, Miao $Y$, Chen $Y T$, Hu ZQ. Minimally invasive approaches to axillary osmidrosis treatment: $A$ comparison between superficial liposuction with automatic shaver curettage, subcutaneous laser treatment, and microwave-based therapy with a modified technique. J Cosmet Dermatol. 2019;18(2):594-601.

5. Endo $T$, Nakayama $Y$. Surgical treatment of axillary osmidrosis. Ann Plast Surg, 1993; 30: 136-139.

6. Tung TC, Wei FC. Excision of subcutaneous tissue for the treatment of axillary osmidrosis. Br J Plast Surg, 1997; 50: 62-66

7. Wu WH, Ma S, Lin JT, Tang YW, Fang RH, Yeh FL. Surgical treatment of axillary osmidrosis: an analysis of 343 cases. Plast Reconstr Surg, 1994; 94: 288-294

8. Chang CK, Chen CY, Hsu KF, Chiu HT, Chu TS, Liu HH, Goh MX, Chen SG. Brachial plexus injury after microwave-based treatment for axillary hyperhidrosis and osmidrosis. J Cosmet Laser Ther. 2017;19(7):439441.

Trop J Pharm Res, October 2020; 19(10): 2044 
9. Martin A, Saathoff $M$, Kuhn F, Max H, Terstegen L, Natsch A. A Functional ABCC11 Allele Is Essential in the Biochemical Formation of Human Axillary Odor. J Invest Dermatol. 2010; 130(2):529-540.

10. World Medical Association Declaration of Helsinki: ethical principles for medical research involving human subjects. JAMA. 2013; 310: 2191-2194.

11. Yabuuchi $H$, Shimizu $H$, Takayanagi S, Ishikawa $T$. Multiple Splicing Variants of Two New Human ATPBinding Cassette Transporters, ABCC11 and ABCC12. Biochem Biophys Res Commun, 2001; 288(4): 933-939.

12. Tammur J, Prades $C$, Arnould I, Rzhetsky A, Hutchinson A, Adachi M, Schuetz JD, Swoboda KJ, Ptácek LJ, Rosier $M$, et al. Two new genes from the human ATPbinding cassette transporter superfamily, ABCC11 and
ABCC12, tandemly duplicated on chromosome 16q12. Genewatch, 2001; 273: 89-96.

13. Wang $\mathrm{H}$, Chi $\mathrm{CH}$, Zhang $Y$, Shi $B$, Jia $R$, Wang $B J$. Effects of histone deacetylase inhibitors on ATP-binding cassette transporters in lung cancer A549 and colorectal cancer HCT116 cells. Oncol Lett. 2019; 18(1):63-71.

14. Martin A, Saathoff M, Kuhn F, Max $H$, Natsch A. A Functional ABCC11 Allele Is Essential in the Biochemical Formation of Human Axillary Odor. J Invest Dermatol, 2010; 130 (2): 529-540

15. Toyoda Y, Takada $T$, Gomi $T$, Nakagawa $H$, Ishikawa $T$, Suzuki H. Clinical and Molecular Evidence of ABCC11 Protein Expression in Axillary Apocrine Glands of Patients with Axillary Osmidrosis. Int $\mathrm{J} \mathrm{Mol}$ Sci. 2017;18(2): E417. 